\title{
Poor response to oral indomethacin therapy for persistent ductus arteriosus in very low birthweight infants
}

\author{
RICHARD W. I. COOKE AND DOUGLAS PICKERING \\ From the University Department of Paediatrics, Fohn Radcliffe Hospital, Oxford, and the Radcliffe \\ Infirmary, Oxford.
}

SUMMARY Administration of oral indomethacin to treat cardiorespiratory failure in 7 low birthweight infants, after failure of conventional therapy, produced an improvement in only 2 infants. These infants had a higher birthweight than the group as a whole. Surgical ligation, rather than oral indomethacin, may be the treatment of choice for persistent ductus arteriosus in very low birthweight infants.

In view of the increasing frequency of persistent ductus arteriosus in neonatal special care units, there has been an increased interest in methods of duct closure. The recent introduction of pharmacological techniques of duct closure by means of indomethacin has led to its widespread use in this condition, in order to avoid surgical ligation as a method of treatment (Friedman et al., 1976; Heymann et al., 1976). However, complications from the use of such drugs have been recorded, and other theoretical risks suggested (Nadas, 1976). In addition, the initial success rate for treatment with indomethacin has not always been supported by studies from other centres (Neal et al., 1977). We report our own experience with indomethacin therapy for persistent ductus arteriosus in low birthweight infants over the past 18 months.

\section{Methods}

Diagnosis of a left to right shunt through a persistent ductus arteriosus was made on clinical grounds, by the presence of a characteristic systolic murmur, together with a wide pulse pressure, radiological evidence of pulmonary plethora, and usually an increase in diameter of the cardiac shadow (Jones and Pickering, 1977). Conventional therapy with digoxin, frusemide, and restriction of fluid intake to less than $150 \mathrm{ml} / \mathrm{kg}$ per day was begun if failure occurred. Failure was defined as increasing requirement for oxygen or respiratory support, or as cardiac failure as evidenced by liver enlargement, tachycardia, and/

Received for publication 5 June 1978 or excessive weight gain. Constant positive airway pressure was usually used to treat recurrent apnoea, which was a common problem if the infant was not ventilated (Roberton, 1974). If clinical improvement did not occur, surgical ligation was performed, and carried a low operative mortality (Cooke et al., 1978). Nevertheless, there was frequently a reluctance to subject small infants to surgery at an early stage as prolonged supportive measures may result in spontaneous recovery, even in severe cases (Roberton, 1974).

However, if such measures include ventilation, infants may die from chronic lung disease before recovery from persistent ductus arteriosus occurs (Nelson et al., 1976; Cooke et al., 1978). To avoid such a situation, indomethacin therapy has been tried before ligation of the ductus in 7 infants.

After at least 48 hours of digoxin and diuretic therapy, with respiratory support as required, indomethacin was administered if no clinical improvement had occurred. $0.2 \mathrm{mg} / \mathrm{kg}$ per dose was given via a nasogastric tube at 12 -hourly intervals for 3 doses. One infant (case 1) had only one dose because of pronounced oliguria. Surgical ligation was carried out if no improvement occurred after 3 doses of indomethacin.

\section{Results}

Seven low birthweight infants received treatment with indomethacin (Table). All had been ventilated. for moderate to severe hyaline membrane disease, and 3 infants were still receiving ventilation at the time of treatment (cases 1, 5, and 7). Mean gesta- 
Table Course of illness treated by oral indomethacin

\begin{tabular}{|c|c|c|c|c|c|c|c|c|}
\hline No. & $\begin{array}{l}\text { Early } \\
\text { illness }\end{array}$ & $\begin{array}{l}\text { Gestation } \\
(w k)\end{array}$ & $\begin{array}{l}\text { Birth- } \\
\text { weight }(g)\end{array}$ & $\begin{array}{l}\text { Time } \\
\text { murmur } \\
\text { first heard }\end{array}$ & $\begin{array}{l}\text { Time of } \\
\text { ductus } \\
\text { 'failure' } \\
\text { developing }\end{array}$ & $\begin{array}{l}\text { Age when } \\
\text { indomethacin } \\
\text { started }\end{array}$ & Result & Outcome \\
\hline 1 & HMD & 25 & 790 & 7 days & 8 & 27 & $\begin{array}{l}\text { No response; } \\
\text { oliguria 1d }\end{array}$ & $\begin{array}{l}\text { Duct ligated } 46 d \text {; died } 127 d \text {; bronchopul- } \\
\text { monary dysplasia }\end{array}$ \\
\hline 2 & HMD & 32 & 1340 & 11 days & 21 & 24 & No response & Duct ligated 29d; did well \\
\hline 3 & HMD & 29 & 1200 & 4 days & 27 & 32 & $\begin{array}{l}\text { No change; } \\
\text { oliguria 1d }\end{array}$ & Duct ligated 35d; did well \\
\hline 4 & HMD & 30 & 1120 & 3 days & 9 & 16 & No response & Duct ligated 19d; did well \\
\hline 5 & HMD & 28 & 1140 & 4 days & 4 & 15 & No response & $\begin{array}{l}\text { Duct ligated } 49 \mathrm{~d} \text {; died } 69 \mathrm{~d} \text {; broncho- } \\
\text { pulmonary dysplasia }\end{array}$ \\
\hline 6 & HMD & 30 & 1440 & 8 days & 21 & 23 & $\begin{array}{l}\text { Symptoms/ } \\
\text { signs reduced } \\
\text { after } 1 \text { dose; off } \\
\text { all therapy } \\
\text { after } 4 \mathrm{~d}\end{array}$ & Continued to do well \\
\hline 7 & HMD & 34 & 2080 & 9 days & 18 & 21 & $\begin{array}{l}\text { Symptoms/ } \\
\text { signs reduced } \\
\text { after } 3 \text { rd dose; } \\
\text { off all therapy } \\
\text { after } 4 \mathrm{~d}\end{array}$ & $\begin{array}{l}\text { Continued gradual improvement complicated } \\
\text { by bronchopulmonary dysplasia }\end{array}$ \\
\hline
\end{tabular}

HMD, hyaline membrane disease; $d$, day.

tional age was $29 \cdot 7$ weeks (range 25 to 34 weeks) and mean birthweight $1300 \mathrm{~g}$ (range 790 to $2080 \mathrm{~g}$ ). The ductus murmur was heard at a median age of 7 days, and failure occurred at a median age of 18 days. Indomethacin was given at a median of 5 days after failure. No response was noted clinically in 5 out of 7 infants. Oliguria occurred in 2 infants, but they recovered within 24 hours. Of the 5 infants in whom indomethacin therapy failed, all had surgical ligation of the ductus, 2 died subsequently at 69 and 127 days from bronchopulmonary dysplasia, probably as a consequence of prolonged mechanical ventilation in the presence of pulmonary plethora. All the other infants survived and did well. In the 2 infants who showed a response to indomethacin (cases 6 and 7), the murmur of persistent ductus arteriosus, though reduced in intensity, persisted in both infants. Other symptoms and signs were much reduced, however, and both infants were off all treatment at $\mathbf{4}$ days after the start of indomethacin treatment. Case 7 subsequently had a recovery prolonged by chronic lung disease, but did well.

\section{Discussion}

In previous published work on the use of indomethacin in the treatment of persistent ductus arteriosus in low birthweight infants, results have been very good, with successful closure of the duct in most if not all cases (Friedman et al., 1976; Heymann et al., 1976); with higher doses of indomethacin than used in our unit, renal failure was common (Friedman et al., 1976; Heymann et al., 1976). In the series reported in this paper, only 2 out of 7 infants avoided surgery because of a response to indomethacin therapy. In these 2 infants, the signs of persistent ductus arteriosus did not disappear completely, but supportive therapy could rapidly be discontinued. Both infants were relatively more mature and of greater birthweight than the group as a whole, and no infant of less than 30 weeks' gestation and $1400 \mathrm{~g}$ birthweight responded to indomethacin therapy. In the series of Friedman et al. (1976) all infants were over $1050 \mathrm{~g}$ birthweight, with an average birthweight of $1500 \mathrm{~g}$, and so comparable with the 2 infants successfully treated in this series. Heymann et al. (1976) included several infants of below $1000 \mathrm{~g}$ in their group of successfully treated infants, but full details of infants in a more extensive study are not available (Heymann and Rudolph, 1977).

The time of administration of indomethacin may be important, as postnatal age and the duration of patency of the ductus may alter its response. We gave the drug relatively late, at between 11 and 28 days after the first clinical signs of the ductus appeared, at a postnatal age of 15 to 32 days. This is considerably later than the time of administration in other series such as that of Heymann et al. (1976). When observed at operation, the ducts that failed to close were of large diameter and thin walled, and it was not difficult to attribute the failure of closure to lack of muscular tissue in the duct wall. It is not possible to say for certain whether this was an acquired feature, but it does seem probable.

In conclusion, it seems that indomethacin may not prove useful in the treatment of very low birthweight infants with persistent ductus arteriosus, at 
least at a late stage of the illness. In larger infants who develop cardiorespiratory failure secondary to persistent ductus arteriosus, a trial of indomethacin therapy may avoid the necessity of surgical ligation.

\section{References}

Cooke, R. W. I., Gribbin, B., Gunning, A. J., and Pickering, D. (1978). Ligation of patent ductus arteriosus in the very low birthweight newborn infant. Archives of Disease in Childhood, 53, 271-275.

Friedman, W. F., Hirschklau, M. J., Printz, M. P., Pitlick, P. T., and Kirkpatrick, S. E. (1976). Pharmacologic closure of patent ductus arteriosus in the premature infant. New England fournal of Medicine, 295, 526-529.

Heymann, M. A., and Rudolph, A. M. (1977). Evaluation of indomethacin in closure of the ductus arteriosus (abstract). Circulation, 55 and 56, Suppl. III, 192.

Heymann, M. A., Rudolph, A. M., and Silverman, N. H. (1976). Closure of the ductus arteriosus in premature infants by inhibition of prostaglandin synthesis. New England
Fournal of Medicine, 295, 530-533.

Jones, R. W. A., and Pickering, D. (1977). Persistent ductus arteriosus complicating the respiratory distress syndrome. Archives of Disease in Childhood, 52, 274-281.

Nadas, A. S. (1976). Patent ductus revisited. New England Fournal of Medicine, 295, 563-565.

Neal, W. A., Kyle, J. M., and Mullet, M. D. (1977). Failure of indomethacin therapy to induce closure of patent ductus arteriosus in premature infants with respiratory distress syndrome. Fournal of Pediatrics, 91, 621-623.

Nelson, R. J., Thibeault, D. W., Emmanouilides, G. C., and Lippmann, M. (1976). Improving the results of ligation of patent ductus arteriosus in small pre-term infants. Fournal of Thoracic and Cardiovascular Surgery, 71, 169-178.

Roberton, N. R. C. (1974). Prolonged continuous positive airways pressure for pulmonary oedema due to persistent ductus arteriosus in the newborn. Archives of Disease in Childhood, 49, 585-587.

Requests for reprints to Dr Douglas Pickering, Department of Paediatrics, The Radcliffe Infirmary, Oxford OX2 6HE. 